\title{
Debt and Subjective Well-Being: Does the Type of Debt Matter?
}

\author{
Tristan Coste*, Caroline Henchoz ${ }^{* *}$, Boris Wernli***
}

\begin{abstract}
Based on longitudinal analyses of data from the Swiss Household Panel, this paper investigates the effect of different types of debt on two evaluative measures of subjective wellbeing: financial satisfaction and life satisfaction. Payment arrears reduce financial satisfaction more than loans or the accumulation of different types of debt (arrears and loans). This negative effect is stable over time. Conversely, each additional year with arrears decreases life satisfaction, confirming the overall and general negative effect of arrears on all domains of daily life, especially for the elderly.
\end{abstract}

Keywords: Debt, Over-indebtedness, Well-being, Satisfaction, Financial

\section{Endettement et bien-être subjectif: Le type de dette joue-t-il un rôle?}

Résumé: S'appuyant sur des analyses longitudinales des données du Panel Suisse de Ménages, cet article examine l'effet de différents types de dettes sur deux mesures évaluatives du bien-être subjectif: la satisfaction financière et la satisfaction de la vie. Les arriérés de paiement diminuent plus la satisfaction financière que les emprunts ou le cumul de dettes (arriérés et emprunts). Cet effet négatif est stable dans le temps. En revanche, chaque année supplémentaire avec des arriérés diminue la satisfaction de la vie, ce qui confirme l'effet négatif global et général des arriérés sur tous les domaines de la vie quotidienne, tout particulièrement pour les aînés. Mots-clés: Dettes, Surendettement, Bien-être, Satisfaction, Financier

\section{Schulden und subjektives Wohlbefinden: Spielt die Art der Schulden eine Rolle?}

Zusammenfassung: Basierend auf Längsschnittanalysen von Daten des Schweizer Haushalt-Panel untersucht dieser Artikel den Einfluss verschiedener Verschuldungsarten auf zwei Komponenten des subjektiven Wohlbefindens: finanzielle Zufriedenheit und Lebenszufriedenheit. Zahlungsrückstände reduzieren die finanzielle Zufriedenheit mehr als Kredite oder die Kumulierung verschiedener Schuldenarten (Rückstände und Kredite). Dieser negative Effekt ist im Laufe der Zeit stabil. Andererseits verringert jedes weitere Jahr mit Rückständen die Lebenszufriedenheit und bestätigt den allgemeinen und negativen Einfluss von Rückständen auf alle Bereiche des täglichen Lebens, insbesondere für ältere Menschen.

Schlüsselwörter: Schulden, Überschuldung, Wohlbefinden, Zufriedenheit, Finanzen

\footnotetext{
* HES-SO Valais / Wallis, Haute école de travail social, CH-3960 Sierre et Université de Fribourg, Département des Sciences sociales, CH-1700 Fribourg, tristan.coste@unifr.ch

** HES-SO Valais / Wallis, Haute école de travail social, CH-3960 Sierre et Université de Fribourg, Département des Sciences sociales, CH-1700 Fribourg, caroline.henchoz@unifr.ch

*** University of Lausanne, Swiss Centre of Expertise in the Social Sciences (FORS), CH-1015 Lausanne, boris.wernli@unil.ch
} 
In Switzerland as elsewhere, the consequences of debt on subjective well-being (SWB) remain little studied compared to the effect of income (for review, Tay et al. 2017). Yet it is a socially relevant question. On the one hand, the effects of a difficult financial situation on SWB do not only concern the family and individuals but can have wider consequences, particularly at the professional level in terms of productivity and absenteeism (Prawitz et al. 2006). On the other hand, the subjective perception of one's economic situation and its consequences are considered as a relevant indicator to identify situations of over-indebtedness (D'Alessio and Lezzi 2013). Swiss scientific studies have so far focused on identifying the populations most affected by debt and the processes that lead to problematic debt (for example, Christin 2012; Henchoz and Wernli 2012) but we have few indicators and ways to distinguish situations of over-indebtedness, which are of particular concern to the political world and to social intervention. In addition, very few studies detail the effects of debt on SWB in Switzerland (Białowolski 2018). Indeed, Switzerland is particularly under-represented in the literature on debt and SWB (Hiilamo and Grundy 2018). Comparative studies at international and European level also do not include Switzerland in their analyses (Angel and Heitzmann 2015; Clayton et al. 2015; Georgarakos and Fürth 2015).

In international studies, it is often the effect of a loan or mortgage on the SWB that has been analyzed (Fitch et al. 2011; Tay et al. 2017). This does not allow a complete understanding of the Swiss situation, as access to property is one of the lowest in Europe. ${ }^{1}$ In 2017, according to the Swiss Federal Statistical Office (FSO) ${ }^{2}$, the two most common types of debt (excluding mortgage debt) are loans and arrears. The first (leasing, small credit, purchase by instalment, debt with family or friends) concern more than $34 \%$ of the population, the most common being loans linked to the purchase of leased vehicles followed by the purchase on credit of goods for housing (23.3\% and 5.7\% respectively). Arrears in payments concern nearly $19 \%$ of the population. Arrears in taxes or health insurance premiums $(9.9 \%$ and $7.3 \%$ of the population respectively) are the most common. This is due in particular to the specific features of the Swiss tax and health insurance system. For most residents, taxes and health insurance premiums are not deducted directly from wages as in other countries but paid individually. In cases of economic difficulty, qualitative studies (Goode 2012; Henchoz and Coste 2017) show that deferring this type of mandatory payment is often perceived as a privileged way to free up some liquidity for more urgent expenses (food, rent, etc.). The question of the link between the type of debt

1 https://ec.europa.eu/eurostat/statisticsexplained/index.php?title=File:R\%C3\%A9partition_de_la_ population_en_fonction_des_modalit\%C3\%A9s_de_jouissance_du_logement,_2016_(en_\%25_ de_la_population)YB18.png (18.06.2019).

2 https://www.bfs.admin.ch/bfs/fr/home/statistiques/situation-economique-sociale-population/ revenus-consommation-et-fortune/endettement.html (09.03.2020). 
and SWB seems therefore very relevant to explore for Switzerland because previous research tend to point out that a payment arrears systematically has a greater impact on health (Turunen and Hiilamo 2014) and financial satisfaction (Tay et al. 2017).

The main objective of this article is to investigate the differential effects of different types of debts (loans and arrears) on two evaluative measures of subjective well-being: financial satisfaction and life satisfaction. To do this, we use the data from the Swiss Household Panel (SHP), which has the advantage of having detailed data on debt and SWB from the beginning and allows us to study this question over the long term. This approach is innovative because longitudinal studies are rare in this field (Richardson et al. 2017; Tay et al. 2017). Analyzing the differential effects of different types of debt will also allow us to identify the situations at risk of overindebtedness and the most damaging to SWB.

\section{The differential effects of debt on SWB: A theoretical framework}

In the scientific literature, economic security is considered as one of the essential components characterizing the SWB of populations (Osberg and Sharpe 2002). However, it has mainly been approached through income, which explains why there are comparatively fewer studies focusing on the effect of debt (Tay et al. 2017). The diversity of ways of conceptualizing debt (Fitch et al. 2011) and the difficulty in quantifying the amount of debt faced by households (Betti et al. 2007) also explains the relatively small number of studies on the subject.

As highlighted in systematic reviews, both debt and SWB indicators are chosen and defined differently according to the research (Fitch et al. 2011; Tay et al. 2017; Turunen and Hiilamo 2014). Although indebtedness is a multidimensional situation that includes loans, leasing or arrears in payments, many studies do not differentiate between types of debt (Fitch et al. 2011). Finally, the definition of SWB and the distinction between well-being and mental health is not always clear, as SWB is an indicator that was empirically constructed before being more formalized (Tay et al. 2017). In the early 1980s, researchers broke down SWB into three distinct components: life satisfaction, positive affect and negative affect (Diener 1984; Diener et al. 1985). Diener et al. (1999) later added satisfaction in specific life domains (health, finance or leisure, etc.)

These different points make it difficult to compare and update trends and explain the sometimes contradictory results. However, we can identify some key points that are relevant to our analysis.

Based on a general definition of debt "as the financial obligation one has to render to another person or institution" (Tay et al. 2017, 908), the scientific literature has focused on the effects of mortgages and loans on mental health and SWB (Fitch et al. 2011). In their systematic review, Tay et al (2017) noted the significant 
association between debt and SWB decline (see also, Brown and Gray 2016; Shen et al. 2014). However, the results are more mixed when looking at the effect of different types of debt on health and SWB (Fitch et al. 2011).

For some, borrowing would have a more negative effect than mortgage credit (Brown and Gray 2016), especially if loans and credits accumulate (Norvilitis et al. 2006). However, according to two longitudinal studies, housing payment problems lead to poorer mental health scores than other types of debt (Nettleton and Burrows 2001; Reading and Reynolds 2001). According to another study, it is rather the consumer debt which have this effect (Brown et al. 2005).

Several international studies have already suggested that loans are less associated with a deterioration of SWB than arrears (Tay et al. 2017). In the same vein, a recent research on the effects of divorce on debt in Switzerland (Wernli and Henchoz 2018) has found that arrears have more negative effects on life and financial satisfaction than loans, partly because in Switzerland loans and credits are only accessible if households have a certain level of income.

However, other studies suggest that it is not so much the type of debt as the difficulty in repaying financial obligations that matters. According to qualitative studies (Nettleton and Burrows 2001), well-being is mainly affected by the fear of losing one's home or the inconvenience of having difficulty paying mortgage interest (reminder to creditors, etc.). The same observation can be found in quantitative studies (Drentea 2000; Drentea and Reynolds 2012). The likelihood and fear of being in arrears or in default are associated with a higher level of anxiety. However, Drentea (2000) notes the importance of taking all debts into account, as it is not so much the fact of having loans as the overall debt situation that causes feelings of anxiety. The same finding in research with American students indicates that it is less the type of debt than the debt burden that impacts SWB (Archuleta et al. 2013).

It is therefore difficult to conclude in view of these results. As Fitch et al. (2011) note in their review, many studies do not distinguish between "problematic" debts in which he includes arrears in payments, and debts that he calls "normative", i. e. managed and repaid without difficulty. In the same vein, other work (Richardson et al. 2013) focuses on "unsecured debt" (a loan that is not backed by an underlying asset), showing that they have proven effects on physical and mental health but without really defining what this concept covers and what types of debt it encompasses. Therefore, it seems important to consider in our analysis this distinction between two types of debt, namely planned, voluntary and manageable debt (loans) and unplanned, involuntary and sometimes unpredictable debt (arrears). ${ }^{3}$

This distinction makes it possible to better understand certain existing research results. For example, the fact that loans would be less associated with health problems than arrears (Turunen and Hiilamo 2014) or that borrowing money from friends or family would be less psychologically painful than borrowing from credit institutions

3 See our hypotheses for more details. 
(Meltzer et al. 2013). Finally, while most studies highlight the negative effect of debt on health, others note that this relationship may also be positive (Berger et al. 2015). Manageable debts can have a positive effect on SWB and health by increasing consumption capacity and financial flexibility (Clayton et al. 2015). However, this effect may change over time, and become negative if you lose the ability to manage your debt (Richardson et al. 2013) or if the debt continues (Clayton et al. 2015).

\section{Indicators and hypotheses}

\subsection{Indicators of debt and SWB}

Before presenting our hypotheses, it is necessary to specify and describe the indicators we have chosen because they are essential to a clear understanding of the rest of the discussion.

\section{Debt indicators (Independent variables)}

The SHP data do not make it possible to determine the overall amount of a household's debts, but they do contain indicators that make it possible to analyze and distinguish two key dimensions of debt that we have highlighted above: loans and arrears.

These 2 indicators make it possible to distinguish between 3 debt situations:

1. Loans ${ }^{4}$

2. Arrears ${ }^{5}$

3. Cumulation (Loans + Arrears)

\section{SWB indicators (dependent variables)}

In the scientific literature, SWB is generally studied in two distinct dimensions: the affective dimension and the evaluative dimension (Diener 1984; Diener et al. 1985; 1999). The first one is how debt influences the frequency of positive feelings (strength, energy, optimism) and the frequency of negative feelings (blues, despair, anxiety or depression). The second one concerns the effect of debt on the evaluation of satisfaction, which can be done in a specific domain (housing, leisure, finance, etc.) or globally, in life in general. To better highlight these differentiated effects of

$4 \quad$ "Since (month, year), have you, or another member of the household, paid monthly premiums linked to a loan, a debt or a leasing, not including mortgage?" ( $1=$ yes; $2=$ no).

5 "Since (month, year) have you experienced problems which resulted in arrears in payments of your household bills?” (1 =yes; 2 = no). 
debt, we have chosen to focus on the evaluative dimension, more specifically on two indicators: financial satisfaction ${ }^{6}$ and life satisfaction in general. ${ }^{7}$

The first indicator, financial satisfaction (Diener et al. 1999) is particularly interesting to consider for several reasons. First, there are a limited number of studies which explore the determinants of financial satisfaction and within this literature, relatively few studies focus on the role of household debt (Brown and Gray 2016). Second, the concept of financial satisfaction includes both objective and subjective measures: income, amount of debt, level of savings, ability to handle financial stress, perception of financial outcomes and money management skills (Hira and Mugenda 1998). Consequently, this indicator seems relevant to assess the debt burden and the plannable and manageable dimension of our three debt situations (Brüggen et al. 2017). The second indicator, life satisfaction in general (Diener et al. 1985), is useful to understand to what extent certain debt situations have consequences that go beyond the strictly financial domain. On the theoretical level, these two indicators are strongly interrelated, as synthesized pertinently by Tay et al. $(2017,909)$ in their conceptual model: a "bottom-up spillover perspective posits that overall SWB is psychologically constructed from domain satisfactions; that is, overall SWB is derived from a sense of whether different life domains are satisfactory (Kahneman 1999), with each domain weighted by its importance to life goals (Oishi et al. 2001). Financial well-being is one of the key life domains for overall SWB (Diener et al. 1999), and the occurrence of debt can adversely affect financial satisfaction and, subsequently, overall SWB. Furthermore, because the financial domain undergirds opportunities and costs for a variety of life domains, financial well-being likely exerts spillover effects that influence other life domains such as marriage, family, and leisure".

Both indicators are captured by a single measure, which raises the question of their validity and their reliability. However, previous research has identified many examples where single-element measures work well, as well as multiple-element measures (Cheung and Lucas 2012). Lucas and Donnellan (2012) showed specifically that in large panels, life satisfaction measures with a single item yielded results almost identical to those with several items such as the life satisfaction scale.

\subsection{Hypotheses}

We have retained two main research hypotheses to test in this article. The first hypothesis plays a central role in our article by analyzing several debt situations and their respective effects on our SWB indicators.

H1: The differential effects of different types of debt on SWB

$6 \quad$ "Overall how are you satisfied with your financial situation?" (11-point scale with 0 means "not at all satisfied" and 10 means "completely satisfied").

7 "In general, how satisfied are you with your life?" (same response modalities). 
By integrating several debt and SWB indicators into our analysis models, we will be able to test in detail the general assumption that not all debt situations have the same impact on SWB.

H1.1: Borrowing (loans) increases financial satisfaction but has little effect on life satisfaction

In Switzerland, loans are the closest to planned, voluntary and manageable debts (Fitch et al. 2011; Richardson et al. 2013). The monthly payments and interest due are predictable because they are defined by law and contractualized. In addition, under current Swiss law, the lender is required to verify the financial capacity of the debtor to repay the loan within 36 months. In other words, loans are available to individuals and households whose budgets will not be disrupted by this debt and who are supposed to have the means to repay it without jeopardizing their standard of living (Henchoz and Wernli 2012). Therefore, as others have already pointed out, we assume that, in the Swiss context, borrowing can have a positive effect on financial satisfaction (Berger et al. 2015). They are manageable, predictable and plannable debts that can increase consumption capacity and financial flexibility (Clayton et al. 2015). In this sense, we assume that borrowing has no effect on life satisfaction or a slight positive effect because it provides opportunities for financing leisure and other activities that can strengthen this dimension of SWB. However, it is expected that the effect will be non-existent or very little positive because the effect is short-term, with loans having to be repaid. ${ }^{8}$

H1.2: Payment arrears reduce financial and life satisfaction

We consider arrears as "unmanageable debt", debt that is unpredictable and difficult to plan for several reasons. Firstly, there is no law setting reminder fees. As a result, they are difficult to predict and can sometimes reach significant amounts that do not allow for adequate reimbursement planning. Secondly, arrears are frequently associated with economic difficulties and financial stress. This is due in particular to creditor recovery actions (Hiilamo and Grundy 2018) and the anxiety and uncertainty involved (Drentea 2000). Consequently, arrears would reduce both indicators of SWB examined (Białowolski 2018).

H1.3: The accumulation of debts (loans and arrears) is the debt situation that most negatively affects financial and life satisfaction

The accumulation of different types of debt is often considered as one of the signs of over-indebtedness (European Commission 2008), i. e. a situation where household income, in spite of a reduction of the living standard, is insufficient to discharge all payment obligations over a long period of time. In Switzerland, there is no quantitative measure of over-indebtedness. The FSO also tries to assess over-indebtedness

8 See Hypothesis 2 
by measuring the accumulation of different types of debt (leasing, small loan or consumer loan purchase by instalment, debt with family or friends not living in the household, arrears, bank overdraft or unpaid by credit card). This debt situation concerned less than $20 \%$ of the population in $2017^{9}$. Qualitative research also seems to confirm that debt accumulation is often a sign of over-indebtedness or, in any case, of difficulties in coping with debt by trying to find funds through different means (Henchoz and Coste 2017). We therefore assume that the accumulation of loans and arrears is the debt situation that will most negatively affect financial and life satisfaction.

Table 1 Summary of hypotheses related to the differentiated effects of debt on SWB

\begin{tabular}{lcc}
\hline & Financial Satisfaction & Life satisfaction \\
\hline Loans & + & No effect \\
Arrears & - & - \\
Cumulation & -- & - \\
\hline
\end{tabular}

In order to deepen this first central hypothesis, we propose a complementary hypothesis related to the temporal dimension of the link between debt and SWB. In our view, the differentiated effects of the types of debt are mitigated or reinforced by this dimension.

$\mathrm{H} 2$ : The duration of debt will have a different effect on SWB depending on the type of debt

Financial and life satisfaction are dynamic in that individuals' evaluations of a situation can change over time (Brüggen et al. 2017). We therefore hypothesize that the duration of debt will have a different effect on SWB depending on the type of debt:

H2.1: Borrowing (loans) is a planned debt and therefore has a constant effect over time

We therefore expect no change in both dimensions of the satisfaction examined over time.

H2.2: Arrears are unplanned debt and will have a differentiated effect over time We expect a negative impact on financial satisfaction if the situation continues (Clayton et al. 2015) because it implies an increasing difficulty in managing debt (Richardson et al. 2013). However, we expect that the negative impact of debt on life satisfaction will decrease over time as individuals will become accustomed to

9 http://www.bfs.admin.ch/bfs/fr/home/statistiques/situation-economique-sociale-population/ revenus-consommation-et-fortune/endettement.html (09.03.2020). 
the situation. We hypothesize a habituation mechanism; that is, a form of learning about the debt situation that results in a decrease in the intensity and frequency of its negative effects (Shen et al. 2014).

H2.3: On the contrary, the accumulation of debts does not imply any habituation effect because the situation is constantly changing

Negative effects add up and this implies permanent adjustments by the persons concerned (Henchoz and Coste 2017). Consequently, we expect that the impact on the two satisfaction indicators will be reinforced as a function of the duration of the debt.

Table 2 Summary of hypotheses related to the temporal dimension of debt on SWB

\begin{tabular}{lcc}
\hline & Financial Satisfaction & Life satisfaction \\
\hline Loans & No effect & No effect \\
Arrears & - & Effect tends towards zero \\
Cumulation & -- & -- \\
\hline
\end{tabular}

\section{$4 \quad$ Data and analytical strategy}

\subsection{Data}

The empirical test of our hypotheses is based on data from the $\mathrm{SHP}^{10}$, a representative multi-thematic longitudinal survey conducted by the Swiss Foundation for Social Science Research ${ }^{11}$ and funded by the Swiss National Science Foundation (SNSF). Since 1999 (wave 1), all members aged 14 and over of the selected households have been interviewed annually, mainly by telephone. In 1999, the first random sample consisted of 5074 households and 12931 individuals. Since 2004, a second random sample (2538 households and 6569 individuals) and a third one from 2013 (3988 households and 9881 individuals) have been followed, according to the same principle.

In order to control selection biases as much as possible and to take into account part of endogeneity, we retain in our longitudinal analyses only those individuals who are not indebted at the time of their first observation, to examine the effect of debt on SWB when and if it occurs. As not all of the selected debt and SWB indicators were introduced at the same time into the SHP questionnaire our samples vary slightly. It ranges from a minimum of 118966 complete observations on all variables considered, relating to 19803 different individuals, to a maximum of 129201 observations, collected from 21220 cases (SHP waves 1 to 19 for financial

10 www.swisspanel.ch

11 www.forscenter.ch 
satisfaction, 2 to 19 for life satisfaction). In average we count between 6.0 and 6.1 observations per person.

\subsection{Analytical strategy}

Our analyses are conducted using fixed-effect linear longitudinal models (RabeHesketh et al. 2012), since we model dependent variables measured on a scale from 0 to 10 . These models take the form of the following equation:

$$
\begin{aligned}
& Y_{i t}-\bar{Y}_{i}=\beta_{1} \cdot\left(x_{1 i t}-\bar{x}_{1 i}\right)+\ldots+\beta_{p} \cdot\left(x_{p i t}-\bar{x}_{p i}\right)+\left(\varepsilon_{i t}-\bar{\varepsilon}_{i}\right) \\
& \text { where } i=\text { person index and } t=\text { time index }
\end{aligned}
$$

For each observation at a time $t$ for an individual $i$, we explain the difference between the dependent variable $\mathrm{Y}$ and the mean level of it for all observations of this same individual, by the difference between each independent variable $\mathrm{X}$ and the mean level of it, always for a given individual. These fixed-effect models therefore explain a difference in state on Y by a difference on the X's parameters and are therefore particularly suitable for causal analysis (a change explains a change). By focusing on intra-individual variance, they allow us to control part of the endogeneity of the explanatory models by eliminating the influence of unmeasured parameters that would remain stable over time.

We test the effect of loans and arrears in separate models in order to highlight their respective impacts, each time starting with samples of people not in debt on this specific dimension. Concerning the impact of the accumulation of the two types of debts, we measure it by introducing an interaction effect which materializes their joint occurrence, in addition to the distinct effect of arrears and loans. In that case, analyses are based on a sample of people who did not have any arrears at the time of their first observation. We opted for this strategy because few people passed from a situation of non-debt to a cumulative situation within a year.

Our analyses are controlled by different parameters that may vary over time. Time variant variables are age, whose square is also considered to form a curvilinear relationship, labour force participation rate, annual net household income, whether or not interviewees live in a couple, health status and the extent to which respondents are restricted in their daily activities by the latter.

In our analyses, we also consider several invariant variables, normally ignored in fixed-effect models, that interact with debt indicators in order to verify whether they have a differentiated impact on SWB for certain categories of respondents. These invariant variables refer to nationality (Swiss or non-Swiss), language region of residence (German, French or Italian-speaking Switzerland), birth cohort (1958 and before, 1959 to 1978,1979 and after), sex, education level in three groups (compulsory schooling, vocational training, higher education) and the tertile of the household's net annual income. When intra-individual variations on these pa- 
rameters are observed during the duration of the panel ${ }^{12}$, we considered respectively that Swiss nationality, membership of a minority language region, maximum level of education and average annual income during the period under review were the criteria for allocation to these groups throughout the whole period under review.

To measure the temporal effect of debt, we use time counters that measure years of debt from their occurrence. These remain at 0 when the household is not indebted and increase by one unit for each additional year of debt, without considering a specific threshold for simplification purposes.

\section{Results}

\subsection{Descriptive results}

Table 3 compares four different debt situations (neither loans nor arrears, only loans, only arrears and cumulation). It does not allow us to conclude whether the discrepancies identified are caused by the occurrence of loans or arrears but provides several inputs and leads that we will briefly detail in relation to our hypotheses.

Table 3 shows that, overall, indebted people experience lower financial and life satisfaction than debt-free people. The difference is particularly marked for people living in households with arrears and accumulated debt, which tends to confirm our assumptions. Members of these two groups are significantly less satisfied financially than people who have loans or no debt. (respectively an average satisfaction level of 5.3 when in arrears, 5.2 with debt accumulation against 6.9 with loans and 7.5 without debt). The same can be said for life satisfaction (7.3 and 7.4. against 8.0 and 8.2 respectively).

Table 3 provides possible explanations. Thus, people in debt have less ability to save money than people without debt. They are also more likely to spend what they earn or eat into savings and assets and get into debt. At this stage, our results also confirm that economic capacities and practices differ according to the type of debt. In general, people with arrears and accumulated debt are in the most difficult financial situations than people living in households with only loans. The ability to save is the lowest among these two groups (respectively $15 \%$ and $12 \%$ compared to $60 \%$ for debt-free people and $51 \%$ for people with loans). There are more people in these groups who spend what they earn $(61 \%$ with arrears and $60 \%$ with cumulation against $44 \%$ with loans and $33 \%$ without debt). More worryingly, more people living in households with arrears or accumulated debt are drawing on their savings (17\% and $13 \%$ ) than other groups (7\% without debt and $4 \%$ with loans). At this stage, two explanations can be proposed for the fact that people with a loan

12 Indeed, apart from birth cohort and sex, it is possible, even if cases are rare, to acquire Swiss nationality, to change language region, education level or income tertile from one interview to the next. 
Table 3 Descriptive statistics according to debt situation average and percentage

\begin{tabular}{|c|c|c|c|c|c|}
\hline & $\begin{array}{l}\text { neither loans } \\
\text { nor arrears }\end{array}$ & only loans & only arrears & $\begin{array}{c}\text { loans and } \\
\text { arrears }\end{array}$ & $\begin{array}{l}\mathrm{n} \text { obser- } \\
\text { vations }\end{array}$ \\
\hline \multicolumn{6}{|l|}{ sociodemographic variables } \\
\hline men & $79 \%$ & $12 \%$ & $5 \%$ & $4 \%$ & 65726 \\
\hline women & $80 \%$ & $11 \%$ & $6 \%$ & $3 \%$ & 80712 \\
\hline 1979 or younger & $74 \%$ & $14 \%$ & $8 \%$ & $5 \%$ & 31310 \\
\hline 1959-78 & $72 \%$ & $16 \%$ & $7 \%$ & $5 \%$ & 51754 \\
\hline 1958 or older & $89 \%$ & $6 \%$ & $3 \%$ & $2 \%$ & 63373 \\
\hline Swiss citizenship & $81 \%$ & $11 \%$ & $5 \%$ & $3 \%$ & 136851 \\
\hline foreign citizenship & $67 \%$ & $18 \%$ & $8 \%$ & $7 \%$ & 9587 \\
\hline \multicolumn{6}{|l|}{ level of education } \\
\hline low & $77 \%$ & $11 \%$ & $7 \%$ & $5 \%$ & 22755 \\
\hline middle & $79 \%$ & $12 \%$ & $5 \%$ & $4 \%$ & 68537 \\
\hline high & $82 \%$ & $11 \%$ & $5 \%$ & $3 \%$ & 55144 \\
\hline \multicolumn{6}{|l|}{ linguistic region } \\
\hline Swiss german & $85 \%$ & $8 \%$ & $5 \%$ & $2 \%$ & 100481 \\
\hline Swiss french & $69 \%$ & $18 \%$ & $7 \%$ & $6 \%$ & 38969 \\
\hline Swiss italian & $73 \%$ & $17 \%$ & $5 \%$ & $5 \%$ & 6869 \\
\hline \multicolumn{6}{|l|}{ variables related to household income } \\
\hline $\begin{array}{l}\text { net annual household income, not } \\
\text { ajusted }\end{array}$ & 114006 & 129396 & 84838 & 98334 & 136068 \\
\hline $\begin{array}{l}\text { net annual household income, } \\
\text { ajusted OECD }\end{array}$ & 65839 & 68186 & 44731 & 51278 & 134071 \\
\hline \multicolumn{6}{|c|}{ assessment of household income and expenses } \\
\hline hh can save money & $60 \%$ & $51 \%$ & $15 \%$ & $12 \%$ & 79042 \\
\hline hh spends what it earns & $33 \%$ & $44 \%$ & $61 \%$ & $60 \%$ & 52704 \\
\hline hhs eats into savings and assets & $7 \%$ & $4 \%$ & $17 \%$ & $13 \%$ & 11104 \\
\hline hh gets into debts & $0 \%$ & $1 \%$ & $7 \%$ & $16 \%$ & 1805 \\
\hline \multicolumn{6}{|l|}{ satisfaction variables } \\
\hline $\begin{array}{l}\text { satisfaction of financial situation: } \\
\text { mean }- \text { p. }<0.001-\text { Eta } 0.30\end{array}$ & 7.50 & 6.88 & 5.35 & 5.23 & 145993 \\
\hline $\begin{array}{l}\text { satisfaction of financial situation: } \\
\text { standard deviation }\end{array}$ & 1.95 & 2.01 & 2.57 & 2.55 & \\
\hline $\begin{array}{l}\text { satisfaction of financial situation: } \\
\text { standard error of the mean }\end{array}$ & 0.01 & 0.02 & 0.03 & 0.04 & \\
\hline $\begin{array}{l}\text { satisfaction of life in general: } \\
\text { mean }-p .<0.001-\text { Eta } 0.17\end{array}$ & 8.15 & 8.03 & 7.30 & 7.36 & 138583 \\
\hline $\begin{array}{l}\text { satisfaction of life in general: } \\
\text { standard deviation }\end{array}$ & 1.34 & 1.34 & 1.89 & 1.80 & \\
\hline $\begin{array}{l}\text { satisfaction of life in general: } \\
\text { standard error of the mean }\end{array}$ & 0.00 & 0.01 & 0.02 & 0.03 & \\
\hline
\end{tabular}


are the least likely to draw from savings. On the one hand, they are the ones who benefit from the highest net annual household income. On the other hand, it could also mean that our assumption that a loan offers some financial flexibility at least initially tends to be confirmed.

Finally, we see that accumulating different types of debt presents the greatest risk of entering a spiral of over-indebtedness since $16 \%$ of people in households that accumulate get into debts compared to $7 \%$ for those in arrears and $1 \%$ for those with loan and $0 \%$ for those without debt.

Table 3 also confirms the FSO's results ${ }^{13}$, that not everyone is affected by these debt situations. Thus, the differences between linguistic regions regarding debt situations are significant. Indeed, $85 \%$ of the German-speaking Swiss have no debt compared to 69\% of the French-speaking Swiss and 73\% of the Italian-speaking Swiss. While there are no major differences in the fact of having arrears (respectively 5\% of German-speaking Swiss compared to 7\% of French-speaking Swiss and 5\% of Italian-speaking Swiss), households with loans are much more numerous (18\% of French-speaking Swiss and 17\% of Italian-Speaking Swiss compared to 8\% of German-speaking Swiss). The same observation can be made with regard to debt accumulation (2\% Swiss Germans against 6\% Swiss French and 5\% Swiss Italians).

Swiss people are also less indebted than foreigners. $81 \%$ of Swiss have no debt compared to $67 \%$ of foreigners. Finally, we see that the younger you are, the more likely you are to be in debt.

\subsection{Longitudinal results}

\subsubsection{Effects differentiated by type of debt (H1)}

\section{Becoming indebted mainly affects financial satisfaction but in different ways depending on the type of debt}

Our analyses confirm that entering a debt situation has a significant effect on SWB. In all types of debt, financial satisfaction is more affected than life satisfaction. These results confirm the fact that the level of financial satisfaction is more directly impacted by debt than life satisfaction. Our results assert the existence of different effects on SWB depending on the type of debt (H1). Having a loan has a negative impact on financial satisfaction $(-0.34$; Table 4$)$ but less than having arrears $(-0.63$; Table 5) or accumulated debts $(-0.36) \cdot .^{14}$

Having arrears or accumulating debts also affects life satisfaction

13 https://www.bfs.admin.ch/bfs/fr/home/statistiques/situation-economique-sociale-population/ revenus-consommation-et-fortune/endettement.html (09.03.2020).

14 In detail: $-0.36=-0.71$ (arrears) $+(-0.06$ (loans) $)+0.41$ (arrears*loans). Table and detailed results for accumulated debts are available from the corresponding author upon request. 
As expected, the effect of different types of debt on life satisfaction is more nuanced. In line with our hypothesis (H1.1), loans do not have a significant impact on life satisfaction in general. This result tends to confirm that loans represent a short-term benefit but have no lasting effect (because they will have to be repaid), which explains why this does not affect our life satisfaction indicator. Our result attest that payment arrears reduce financial and life satisfaction (H1.2). Arrears represent the type of debt that has the most negative effect on overall life satisfaction (-0.39; Table 5). It is less important than on financial satisfaction (-0.63; Table 5), which confirms the fact that life satisfaction includes elements other than economic dimensions. However, the financial concerns associated with late payments are significant enough to have an impact on all dimensions of life.

\section{Having arrears has the most negative impact on both satisfaction indicators}

Contrary to our initial assumption (H1.3), accumulating both types of debt does not affect life satisfaction more than having only arrears $(-0.29$ against -0.39 ; See Table 5). ${ }^{15}$ When we examine the effect of accumulation more closely, by breaking down the different terms of the model (arrears, loans and the interaction term, i. e. joint presence of both), we see that the impact of arrears is central and highly significant. ${ }^{16}$ However, the distinct effects of borrowing and cumulating debts are not significant.

We also observe a lesser effect of cumulation on financial satisfaction compared to arrears. It could be explained by the fact that taking a loan helps to alleviate the financial situation, at least for a certain period of time. This may also be due to that arrears prevail because of their unpredictability and difficulty in managing, with a legal framework that protects the indebted household less, as well as to the stress associated to this uncomfortable situation. In addition, subsequent analyses have shown that the accumulation of the two types of debt affects a very specific population, which is younger, less educated, with a higher proportion of foreigners, and above all with levels of satisfaction (with life in general and with the financial situation) already lower than normal, even before being in debt.

\section{Older people and the more educated are most affected in their satisfaction}

When we look at some certain social subgroups, we see that the older people and the more educated are most affected in case of arrears or accumulation. With arrears (Table 5), the impact is always greater for the oldest cohorts than the youngest (1979 and later) for both financial satisfaction $(-0.23$ for the intermediate group, -0.25 for the oldest) and life satisfaction ( -0.09 for the intermediate group, -0.20 for the oldest). People with a higher education are also more impacted both in their financial satisfaction $(-0.19)$ and in their life satisfaction $(-0.08$, at the limit of significance

15 The difference should not be overemphasized, since interaction effects are not the same in the models and that all impacts are highly conditional. We conclude instead that the impact of arrears only on life satisfaction is similar to those of the accumulation of both types of debt.

The sole effect of arrears on life satisfaction is $-0.29 ; \mathrm{p}<0.001$. 
Table 4 Fixed effects regression results: loans and SWB

\begin{tabular}{|c|c|c|c|c|}
\hline & \multicolumn{2}{|c|}{ life satisfaction } & \multicolumn{2}{|c|}{ financial satisfaction } \\
\hline & Coef. & $P>t$ & Coef. & $P>t$ \\
\hline age in years & -0.050 & 0.000 & -0.085 & 0.000 \\
\hline squared age & 0.000 & 0.000 & 0.001 & 0.000 \\
\hline activity rate $0-100$ & 0.000 & 0.005 & 0.003 & 0.000 \\
\hline net household annual income, in $10000 \mathrm{CHF}$ & 0.002 & 0.000 & 0.000 & 0.008 \\
\hline live as a couple & 0.315 & 0.000 & 0.368 & 0.000 \\
\hline health status $1-5$ & -0.276 & 0.000 & -0.146 & 0.000 \\
\hline health impediment 0-10 & -0.031 & 0.000 & -0.019 & 0.000 \\
\hline loans & -0.077 & 0.241 & -0.339 & 0.000 \\
\hline men*loans & 0.016 & 0.562 & 0.000 & 0.993 \\
\hline \multicolumn{5}{|l|}{ cohort* ${ }^{\star}$ oans (ref. 1979 or younger) } \\
\hline 1959-78 & 0.047 & 0.158 & 0.154 & 0.001 \\
\hline 1958 and before & -0.025 & 0.516 & -0.004 & 0.936 \\
\hline Swiss citizenship*loans & -0.099 & 0.048 & 0.038 & 0.581 \\
\hline \multicolumn{5}{|l|}{ linguistic region*loans (ref. Swiss german) } \\
\hline Swiss french & 0.038 & 0.180 & 0.041 & 0.301 \\
\hline Swiss italian & 0.027 & 0.614 & -0.078 & 0.285 \\
\hline \multicolumn{5}{|l|}{ level of education*loans (ref. low) } \\
\hline middle & 0.075 & 0.077 & 0.107 & 0.069 \\
\hline high & 0.043 & 0.340 & 0.127 & 0.042 \\
\hline \multicolumn{5}{|l|}{ income tertile*loans (ref. $1^{\text {st }}$ tertile) } \\
\hline $2^{\text {nd }}$ income tertile & 0.030 & 0.376 & 0.003 & 0.947 \\
\hline $3^{\text {rd }}$ income tertile & 0.040 & 0.274 & 0.040 & 0.432 \\
\hline intercept & 9.809 & 0.000 & 8.842 & 0.000 \\
\hline n observations & 118168 & & 124918 & \\
\hline $\mathrm{n}$ individuals & 19715 & & 20466 & \\
\hline rsquare within & 0.0379 & & 0.0149 & \\
\hline
\end{tabular}

with $\mathrm{p}=0.09$ ). For our two SWB indicators, income plays a protective role. Indeed, arrears have less negative consequences for the wealthiest third ( 0.21 for financial satisfaction and 0.13 for life satisfaction). Being of Swiss nationality also mitigates the negative effects of arrears on life satisfaction (0.22). Situations of accumulation generate consistent results since here again there is an aggravating effect for the oldest cohort $(-0.18$ but at the limit of significance: $\mathrm{p}=0.08)$ for financial satisfaction and for life satisfaction in general $(-0.26)$. People with a high level of education are also more affected in their life satisfaction $(-0.24)$. 
Table 5

Fixed effects regression results: arrears and SWB

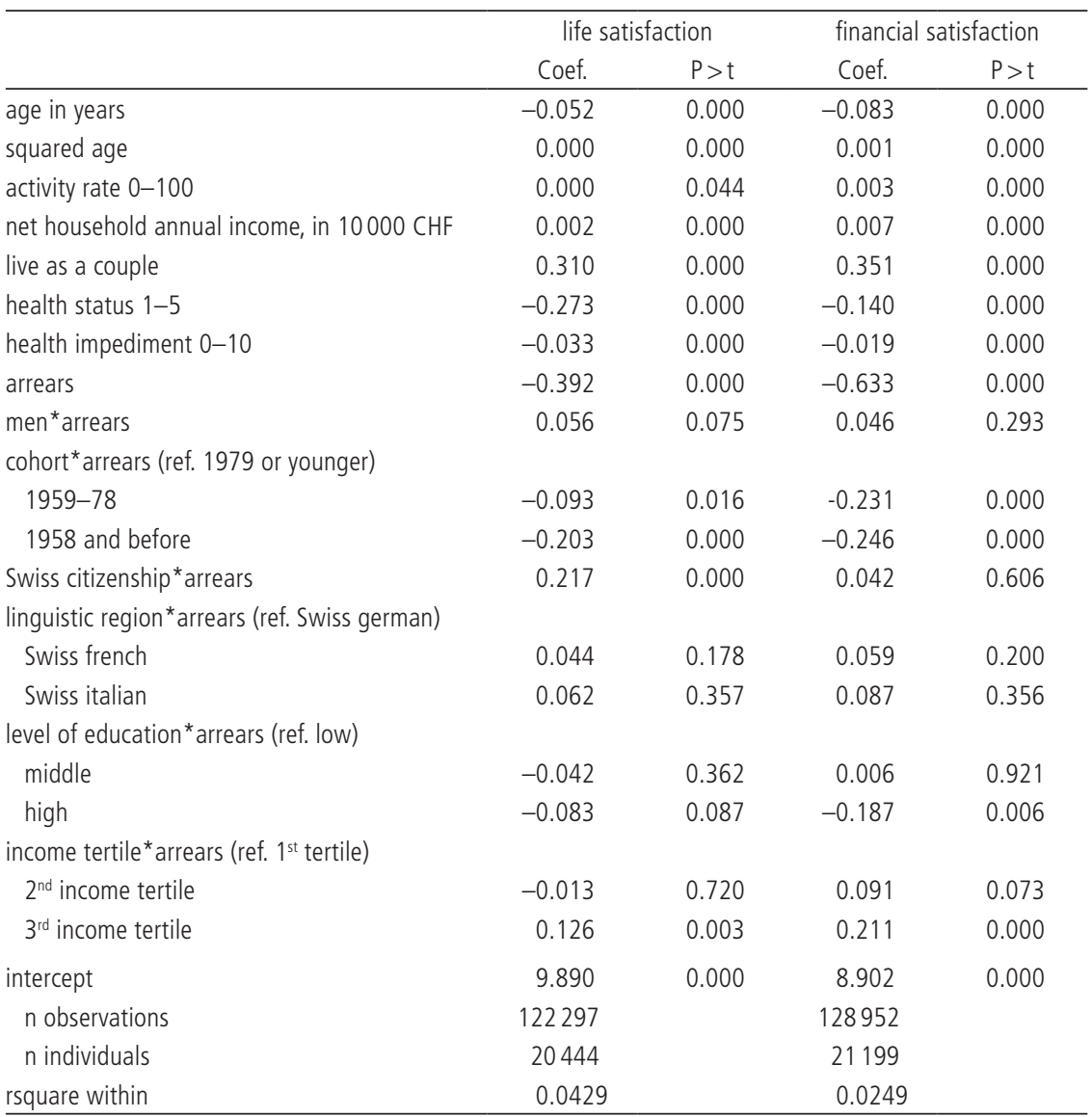

\subsubsection{Temporal effects of debt ( $\mathrm{H} 2)$}

The temporal hypothesis is only partially confirmed because each additional year of debt has more negative effects on life satisfaction and financial satisfaction than expected. In any case, there is no habituation effect (Shen et al. 2014).

If the duration of loans has no significant impact on life satisfaction, which is in line with our assumption (H2.1), the same cannot be confirmed for financial satisfaction. Indeed, each additional year of loans reduces financial satisfaction $(-0.10)^{17}$. Contrary to our hypothesis $(\mathrm{H} 2.1)$, we can't define it as a planned debt with a constant effect. Even if the repayment terms and conditions appear to be more

17 Table and detailed results are available from the corresponding author upon request. 
planned and managed than those related to payment arrears, the negative impact on financial satisfaction is present and must be considered.

The duration of arrears has also effects that are contrary to those expected (H2.2). The duration of arrears does not affect financial satisfaction, while the longer the duration of arrears, the lower the life satisfaction rate $(-0.06$ each year, at the limit of significance with $\mathrm{p}=0.06) .{ }^{18}$ In other words, arrears are the type of debt that most affects financial satisfaction but we can say here that the extra years do not worsen or improve the situation. In a nutshell, financial satisfaction is very deteriorated by the arrival of payment arrears but this negative effect is stable over time. In contrast, it can be observed that each additional year with arrears worsens life satisfaction, which confirms the overall and general negative effect of payment arrears on all dimensions of daily life (Tay et al. 2017). Being confronted with arrears for several years generates lasting and diffuse effects that go beyond the strictly economic domain, which makes it a particularly worrying situation.

Here again, the impact on life satisfaction is stronger $(-0.10)$ for the oldest cohort (1958 and before) than the youngest (1979 and later). Over the years, income plays a protective role because arrears have less negative consequences on life situation for the wealthiest third (0,04 for each supplementary year). ${ }^{19}$

Given the lack of generic impact of the accumulation observed previously, the temporal effect of the accumulation of the two types of debt loses its interest because we do not expect this effect to be differentiated over time. Our analyses, whose results are not reported here, confirm this fact, thus contradicting our hypothesis $(\mathrm{H} 2.3)$ and reinforcing the importance of arrears as a determining negative factor for SWB.

\section{Discussion and conclusion}

This study contributes to research on the effect of debt on satisfaction and more broadly on the financial determinants of SWB in several ways. First, we show that being in debt in Switzerland has a negative effect on evaluative SWB which tendentially increases over the years. In accordance with previous research (Fitch et al. 2011; Tay et al. 2017), we have identified that arrears is the type of debt that have the most negative impact on our two satisfaction indicators. Second, our analyses therefore put into perspective the supposedly particularly problematic effect of the accumulation of different types of debt, which is considered by the FSO and the

18 This result is at the upper limit of significance, but if we consider a counter limited to 4 years instead of a counter increasing to infinity, the p-value decreases significantly, to reach 0.011 , which leads us to consider this result as robust. If the theoretical difference may seem interesting between a time-limited counter and an unlimited one, in fact only a very marginal number of cases exceed 4 years of debt ( 0.1 to $0.3 \%$ of cases). This leads us to consider these two types of counters as equivalent in practice.

19 As stated above, table and detailed results are available from the corresponding author upon request. 
European Commission, for example, as a sign of over-indebtedness. Third, our study shows that the impact of debt on SWB is conditional on belonging in certain social subgroups, specially the elderly and the high level education person with debts are particularly affected. This can be explained by the effect of "social norms and comparisons" (Gathergood 2012) or "social stigmatization" (Georgarakos and Fürth 2015). In these groups, debt levels are low, therefore, being in debt can be difficult for individuals who consider themselves out of the ordinary or more stigmatized. However, not only risk but also protective factors come into play and contribute to explaining the change on SWB: both demographic factors (Swiss citizenship) and belonging to high income class clearly lower the negative impact of debt on SWB. Complementary analyses concerning the emotional dimension of the SWB (Wernli et al. 2020), i. e. the consequences of a debt situation on the frequency of positive and negative affects confirm these three results, especially for the elderly.

More broadly, these results have strong implications for policy makers. Apart from being attentive to particular subgroups, there is a key lesson to be learned in terms of debt prevention and debt relief measures to be put in place, namely that the warning signal must be given and actions taken as soon as payment arrears are present. It is important to underline that in Switzerland, nearly $19 \%$ of the population lives in a household with at least one arrears, mainly tax and health insurance premiums $^{20}$ and that it is the most economically vulnerable population. Therefore, our results also underline the effect of the duration of arrears: life satisfaction deteriorate year after year with the debt burdens. This highlights a problematic aspect of debt management and debt reduction that is characterized by long-term trajectories and a use of debt counselling services that often occurs after several years of indebtedness (Schwarze 1999). For all these reasons, policy measures cannot be limited to consumer protection by restraining access to credit as is mainly the case in Switzerland, but they must also make advisory services more accessible and offer facilities to reduce debt and get out of debt in the same way as other European countries (Angel and Heitzmann 2015).

Finally, our analyses open up other questions that would require further research. We show that the effects of debt extend beyond the financial domain and that all domains of daily life are potentially concerned. However, further studies (e. g. a specific analysis of more satisfaction indicators or in-depth interviews with indebted people) would be needed to better understand the interrelationships between financial and life satisfaction and by extension the specific mechanisms by which debt influences all domains of life. Another issue to explore arises from the fact that debt is measured at the household level and satisfaction at the individual level. The link between a common economic situation and an individual subjective

20 https://www.bfs.admin.ch/bfs/fr/home/statistiques/situation-economique-sociale-population/ revenus-consommation-et-fortune/endettement.html (09.03.2020). 
evaluation remains to be investigated. What are the mechanisms and factors within the household that influence the level of individual satisfaction?

\section{References}

Angel, Stefan, and Karin Heitzmann. 2015. Over-Indebtedness in Europe: The Relevance of CountryLevel Variables for the over-Indebtedness of Private Households. Journal of European Social Policy 25(3):331-351.

Archuleta, Kristy L., Anita Dale, and Scott M. Spann. 2013. College Students and Financial Distress: Exploring Debt, Financial Satisfaction and Financial Anxiety. Journal of Financial Counseling and Planning 24(2):50-62.

Berger, Lawrence M., J. Michael Collins, and Laura Cuesta. 2015. Household Debt and Adult Depressive Symptoms in the United States. Journal of Family and Economic Issues 37(1):42-57.

Betti, Gianni, Neil Dourmashkin, Mariacristina Rossi, and Ya Ping Yin. 2007. Consumer Over-indebtedness in the EU: Measurement and Characteristics. Journal of Economic Studies 34(2):136-156.

Białowolski, Piotr. 2018. Hard Times! How Do Households Cope with Financial Difficulties? Evidence from the Swiss Household Panel. Social Indicators Research 139(1):147-61.

Brown, Sarah, and Daniel Gray. 2016. Household Finances and Well-Being in Australia: An Empirical Analysis of Comparison Effects. Journal of Economic Psychology 53: 17-36.

Brown, Sarah, Karl Taylor, and Stephen Wheatley Price. 2005. Debt and Distress: Evaluating the Psychological Cost of Credit. Journal of Economic Psychology 26(5): 642-663.

Brüggen, Elisabeth C., Jens Hogreve, Maria Holmlund, Sertan Kabadayi, and Martin Löfgren. 2017. Financial Well-Being: A Conceptualization and Research Agenda. Journal of Business Research 79: 228-237.

Cheung, Felix and Richard E. Lucas. 2014. Assessing the Validity of Single-item Life Satisfaction Measures: Results fromt Three Large Samples. Quality of Life Research 23(10): 2809-2818.

Christin, Thomas. 2012. Endettement des Jeunes Adultes. Analyses Complémentaires de l'Endettement des Jeunes Adultes. Neuchatel: FSO (Swiss Federal Statistical Office).

Clayton, Maya, José Lińares-Zegarra, and John O. S. Wilson. 2015. Does Debt Affect Health? Cross Country Evidence on the Debt-Health Nexus. Social Science \& Medicine 130: 51-58.

D’Alessio, Giovanni, and Stefano Lezzi. 2013. Household Over-Indebtedness: Definition and Measurement with Italian Data. Bank of Italy Occasional Paper No. 149.

Diener, Ed. 1984. Subjective Well-Being. Psychological Bulletin 95(3):542-575.

Diener, Ed, Robert A. Emmons, Randy J. Larsen, and Sharon Griffin. 1985. The Satisfaction With Life Scale. Journal of Personality Assessment 49(1): 71-75.

Diener, Ed, Eunkook M. Suh, Richard E. Lucas, and Heidi L. Smith. 1999. Subjective Well-Being: Three Decades of Progress. Psychological Bulletin 125(2): 276-302.

Drentea, Patricia. 2000. Age, Debt and Anxiety. Journal of Health and Social Behavior 41: 437-450.

Drentea, Patricia, and John R. Reynolds. 2012. Neither a Borrower Nor a Lender Be. Journal of Aging and Health 24(4): 673-695.

European Commission. 2008. Towards a Common Operational European Definition of Over-Indebtedness. OEE Etudes. Brussels.

Fitch, Chris, Sarah Hamilton, Paul Bassett, and Ryan Davey. 2011. The Relationship between Personal Debt and Mental Health: A Systematic Review. Mental Health Review Journal 16(4): 153-166. 
Gathergood, John. 2012. Debt and Depression: Causal Links and Social Norm Effects. The Economic Journal 122(563): 1094-1140.

Georgarakos, Dimitris, and Sven Fürth. 2015. Household Repayment Behavior: The Role of Social Capital and Institutional, Political, and Religious Beliefs. European Journal of Political Economy 37: 249-265.

Goode, Jackie. 2012. Feeding the Family When the Wolf's at the Door: The Impact of Over-Indebtedness on Contemporary Foodways in Low-Income Families in the UK. Food and Foodways 20(1): 8-30.

Henchoz, Caroline, and Tristan Coste. 2017. Endettement Problématique des Jeunes et Solidarité Familiale. Recherches Familiales 14(1): 37-48.

Henchoz, Caroline, and Boris Wernli. 2012. Ist die Jugendverschuldung in der Schweiz Höher als jene der Erwachsenen? Die Volkswirtschaft Das Magazin Für Wirtschaftspolitik 1/2: 53-56.

Hiilamo, Aapo, and Emily Grundy. 2018. Household Debt and Depressive Symptoms among Older Adults in Three Continental European Countries. Ageing \& Society 40(2): 1-27.

Hira, Tahira K., and Olive M. Mugenda. 1998. Predictors of Financial Satisfaction: Differences between Retirees and Non Retirees. Journal of Financial Counseling and Planning 9(2): 75-83.

Kahneman, Daniel. 1999. Objective happiness. Pp. 3-25 in Well-being: The Foundations of hedonic Psychology, edited by Daniel Kahneman, Ed Diener, and Norbert Schwarz. New York: Russell Sage Foundation.

Lucas, Richard and Brent Donnellan. 2012. Estimating the Reliability of Single-Item Life Satisfaction Measures: Results from Four National Panel Studies. Social Indicators Research 105(3): 323-331.

Meltzer, Howard, Paul Bebbington, Traolach Brugha, Michael Farrell, and Rachel Jenkins. 2013. The Relationship between Personal Debt and Specific Common Mental Disorders. The European Journal of Public Health 23(1): 108-113.

Nettleton, Sarah, and Roger Burrows. 2001. Families Coping with the Experience of Mortgage Repossession in the 'New Landscape of Precariousness'. Community, Work \& Family 4(3): 253-272.

Norvilitis, Jill M., Michelle M. Merwin, Timothy M. Osberg, Patricia V Roehling, Paul Young, and Michele M. Kamas. 2006. Personality Factors, Money Attitudes, Financial Knowledge, and Credit-Card Debt in College Students. Journal of Applied Social Psychology 36(6): 1395-1413.

Oishi, Shigehiro, Ulrich Schimmack, and Ed Diener. 2001. Pleasures and Subjective Well-Being. European Journal of Personality 15(2): 153-167.

Osberg, Lars, and Andrew Sharpe. 2002. Une Évaluation de l'Indicateur du Bien-Être Économique dans les Pays de l'OCDE. Paper presented at SÉMINAIRE DARES, Paris, France, October 15, 2002.

Prawitz, Aimee D., E. Thomas Garman, Benoit Sorhaindo, Barbara O’Neill, Jinhee Kim, and Patricia Drentea. 2006. InCharge Financial Distress/Financial Well-Being Scale: Development, Administration, and Score Interpretation. Journal of Financial Counseling and Planning 17(1): 34-50.

Rabe-Hesketh, Sophia, and Anders Skrondal. 2012. Multilevel and Longitudinal Modeling Using Stata. College Station: Stata Press.

Reading, Richard, and Shirley Reynolds. 2001. Debt, Social Disadvantage and Maternal Depression. Social Science \& Medicine 53: 441-453.

Richardson, Thomas, Peter Elliott, and Ronald Roberts. 2013. The Relationship between Personal Unsecured Debt and Mental and Physical Health: A Systematic Review and Meta-Analysis. Clinical Psychology Review 33(8): 1148-1162.

Richardson, Thomas, Peter Elliott, Ronald Roberts, and Megan Jansen. 2017. A Longitudinal Study of Financial Difficulties and Mental Health in a National Sample of British Undergraduate Students. Community Mental Health Journal 53(3): 344-352.

Schwarze, Uwe. 1999. Schuldnerkarrieren: Institutionelle Problembearbeitung zwischen Sozialberatung und Finanzmanagement. Ergebnisse einer Empirischen Analyse zu Wegen aus Armut und Privater Überschuldung. Arbeitspapier Sfb186. Bremen: Universität Bremen. 
Shen, Shuying, Abdoul G. Sam, and Eugene Jones. 2014. Credit Card Indebtedness and Psychological Well-Being Over Time: Empirical Evidence from a Household Survey. Journal of Consumer Affairs 48(3): 431-456.

Tay, Louis, Cassondra Batz, Scott Parrigon, and Lauren Kuykendall. 2017. Debt and Subjective Well-Being: The Other Side of the Income-Happiness Coin. Journal of Happiness Studies 18(3): 903-937.

Turunen, Elina, and Heikki Hiilamo. 2014. Health Effects of Indebtedness: A Systematic Review. BMC Public Health 14(1): 1-8.

Wernli, Boris and Caroline Henchoz. 2018. Les effets de genre de la séparation sur l'endettement des hommes et des femmes en Suisse: Une Analyse Longitudinale. Recherches Familiales 15(1): 77-94.

Wernli, Boris, Caroline Henchoz, and Tristan Coste. 2020. Bien-être et endettement: Les conséquences émotionnelles des dettes. Pp. 75-92 in Endettement et surendettement en Suisse: Regards croisés, edited by Caroline Henchoz, Tristan Coste, and Fabrice Plomb. Paris: L'Harmattan. Manuscript in press. 